\title{
Effects of citrus pulp, fish by-product and Bacillus subtilis fermentation biomass on growth performance, nutrient digestibility, and fecal microflora of weanling pigs
}

Hyun Suk Noh', Santosh Laxman Ingale ${ }^{1}$, Su Hyup Lee ${ }^{1}$, Kwang Hyun Kim¹, III Kyong Kwon², Young Hwa Kim³ and Byung Jo Chae ${ }^{1 *}$

\begin{abstract}
An experiment was conducted to investigate the effects of dietary supplementation with citrus pulp, fish by-product, and Bacillus subtilis fermentation biomass on the growth performance, apparent total tract digestibility (ATTD) of nutrients, and fecal microflora of weanling pigs. A total of 180 weaned piglets (Landrace $\times$ Yorkshire $\times$ Duroc) were randomly allotted to three treatments on the basis of body weight (BW). There were six replicate pens in each treatment with 10 piglets per pen. Dietary treatments were corn-soybean meal-based basal diet supplemented with 0 (control), 2.5, and 5.0\% citrus pulp, fish by-product, and B. subtilis fermentation biomass. The isocaloric and isoproteineous experimental diets were fed in mash form in two phases ( $\mathrm{d} 0 \sim 14$, phase I and $\mathrm{d} 15 \sim 28$, phase II). Dietary treatments had significant linear effects on gain to feed ratio (G:F) in all periods, whereas significant linear effects on ATTD of dry matter (DM), gross energy (GE), and ash were only observed in phase I. Piglets fed diet supplemented with $5.0 \%$ citrus pulp, fish by-product, and B. subtilis fermentation biomass showed greater $(p<0.05)$ G:F (phase I, phase II, and overall) as well as ATTD of DM, GE, and ash (phase I) than pigs fed control diet. Dietary treatments also had significant linear effects on total anaerobic bacteria populations by d 14 and 28. In addition, piglets fed diet supplemented with 5.0\% citrus pulp, fish by-product and B. subtilis fermentation biomass showed greater $(p<0.05)$ fecal total anaerobic bacteria populations (d 14 and 28) than pigs fed control diet. Dietary treatments had no significant effects (linear or quadratic) on average daily gain (ADG), average dial feed intake (ADFI; phase I, phase II, and overall), or fecal populations of Bifidobacterium spp., Clostridium spp., and coliforms (d 14 and 28). These results indicate that dietary supplementation with $5.0 \%$ citrus pulp, fish by-product, and B. subtilis fermentation biomass has the potential to improve the feed efficiency, nutrient digestibility, and fecal microflora of weanling pigs.
\end{abstract}

Keywords: Citrus pulp, Bacillus subtilis, Performance, Fecal microflora, Weanling pigs

\section{Background}

Worldwide production of citrus fruits approaches 90 million tons per year [1]. Most of these fruits are squeezed to juice and by-products, including peels, segment membranes, and other parts, which are considered as citrus juice waste or pulp [2]. Due to their high processing cost, most citrus juice industry by-products are dumped into the ocean, leading to environmental

\footnotetext{
* Correspondence: bjchae@kangwon.ac.kr

'Department of Animal Resources Science, College of Animal Life Sciences, Kangwon National University, Chuncheon 200-701, South Korea

Full list of author information is available at the end of the article
}

pollution [3]. Recent approaches advocating the use of citrus juice waste have focused on reduction of its moisture contents and its use as an animal feed [4]. Dried citrus pulp contains relatively large amounts of pectins [5] and soluble carbohydrates [6]. Further, several healthpromoting bioactive compounds such as limonene, hesperidin, naringin, quercetin, and bioflavonoids have been identified in citrus pulp [3,7-9]. Contreras Esquivel et al. [10] and Sen et al. [11] reported that citrus juice industry by-products have the necessary characteristics required for substrates of probiotic growth during fermentation. 
Among probiotic microbes, Bacillus spp. are well known for their ability to produce pectinase using pectin in citrus peel as the sole carbon source [12,13]. Previous have reported that citrus juice waste can be used as a substrate for the growth of $B$. subtilis, and the resulting fermentation biomass has potential for improving the performance, intestinal morphology, and cecal microflora of broilers and weanling pigs [11,14]. Therefore, the objective of the present study was to investigate the effects of dietary supplementation with citrus pulp, fish by-product, and $B$. subtilis fermentation biomass on growth performance, apparent total tract digestibility (ATTD) of nutrients, and fecal microflora in weanling of pigs.

\section{Methods}

The protocol for the present experiment was approved by the Institutional Animal Care and Use Committee of Kangwon National University, Chuncheon, Republic of Korea.

\section{Preparation of fermentation biomass}

The B. subtilis used in the present study was isolated and characterized by Yoo et al. [3] and maintained in the laboratory at $-80^{\circ} \mathrm{C}$ as stock culture. Culture broth medium consisting of $6 \%$ corn steep liquor, $4 \%$ molasses, $0.3 \%$ yeast extract, $0.5 \% \mathrm{KH}_{2} \mathrm{PO}_{4}$, and $0.25 \% \mathrm{~K}_{2} \mathrm{HPO}_{4}$ in distilled water was prepared and autoclaved before being used. Stock culture $(2 \mathrm{~mL})$ was then added to $2 \mathrm{~L}$ of autoclaved culture broth and incubated at $37^{\circ} \mathrm{C}$ at $\mathrm{pH} 7.0$ for $48 \mathrm{~h}$.

The B. subtilis grown on culture broth medium was used as a starter to produce fermentation biomass. Dried citrus pulp and fish by-product with $30 \%$ moisture was used as the sole substrate. The substrate was inoculated with $2 \mathrm{~L}$ of starter per $10 \mathrm{~kg}$ of substrate and fermented for $7 \mathrm{~d}$ at $32^{\circ} \mathrm{C}$ and $\mathrm{pH} 7.0$. After $7 \mathrm{~d}$, the fermentation biomass was dried in a forced-air drying oven at $40^{\circ} \mathrm{C}$ for $72 \mathrm{~h}$.

\section{Animals and experimental design}

A total of 180 weaned piglets (Landrace $\times$ Yorkshire $\times$ Duroc) were randomly allotted to three treatments on the basis of initial body weight (BW). There were six replicate pens in each treatment with 10 piglets per pen. All piglets were clinically healthy at the start of the trial and originated from 20 sows in their third parity. Dietary treatments were corn-soybean meal-based basal diet supplemented with 0 (control), 2.5, and 5.0\% citrus pulp, fish by-product, and B. subtilis fermentation biomass. The citrus pulp, fish by-product and B. subtilis fermentation biomass were added to the weanling pig diets by replacing equal volumes of fish meal. The isocaloric and isoproteineous experimental diets were fed in mash form in two phases $(\mathrm{d} 0 \sim 14$, phase I and d $15 \sim 28$, phase II). Diets for phase I were formulated to contain $3,400 \mathrm{kcal} /$ kg metabolizable energy (ME), 21.0\% crude protein (CP), and $1.6 \%$ lysine (Table 1), whereas diets for phase II were formulated to contain 3,360 kcal/ kg ME, 20.0\% CP, and $1.4 \%$ lysine (Table 2). All diets met or exceeded the nutrient requirements recommended by NRC [15].

The experiment was conducted at the Kangwon National University farm facility. The piglets were housed in partially slatted concrete floor pens $(2.8 \times 5.0 \mathrm{~m})$. The temperature in the barn was $30^{\circ} \mathrm{C}$ at the beginning of the experiment and was slowly reduced to $25^{\circ} \mathrm{C}$ on $\mathrm{d} 8$, after which it was kept constant until the end of the

Table 1 Ingredient and chemical compositions of experimental diets (d $0 \sim 14$; as-fed basis)

\begin{tabular}{|c|c|c|c|}
\hline & \multicolumn{3}{|c|}{$\begin{array}{l}\text { Citrus pulp, fish by-product, } \\
\text { and Bacillus subtilis } \\
\text { fermentation biomass, \% }\end{array}$} \\
\hline & 0 & 2.5 & 5 \\
\hline \multicolumn{4}{|l|}{ Ingredients, \% } \\
\hline Corn & 45.38 & 42.36 & 39.34 \\
\hline Whey powder & 15.38 & 15.38 & 15.38 \\
\hline Deh-SBM & 24.88 & 27.08 & 29.29 \\
\hline Soy oil & 3.00 & 3.00 & 3.00 \\
\hline Fish meal & 5.0 & 2.5 & 0.0 \\
\hline L-lysine (78\%) & 0.50 & 0.51 & 0.52 \\
\hline DL-Methionine (100\%) & 0.12 & 0.14 & 0.15 \\
\hline Choline-chloride (50\%) & 0.07 & 0.07 & 0.07 \\
\hline MCP & 0.50 & 0.79 & 1.08 \\
\hline Limestone & 0.67 & 0.73 & 0.78 \\
\hline Salt & 0.20 & 0.20 & 0.20 \\
\hline Mineral premix ${ }^{1}$ & 0.30 & 0.30 & 0.30 \\
\hline Vitamin premix ${ }^{2}$ & 0.30 & 0.30 & 0.30 \\
\hline $\mathrm{ZnO}$ & 0.34 & 0.34 & 0.34 \\
\hline Sucrose & 3.36 & 3.80 & 4.25 \\
\hline $\begin{array}{l}\text { Citrus pulp, fish by-product, } \\
\text { and Bacillus subtilis fermentation } \\
\text { biomass }\end{array}$ & 0.0 & 2.50 & 5.00 \\
\hline \multicolumn{4}{|l|}{ Calculated chemical composition ${ }^{3}$} \\
\hline $\mathrm{ME}, \mathrm{kcal} / \mathrm{kg}$ & 3,400 & 3,400 & 3,400 \\
\hline $\mathrm{CP}, \%$ & 21.00 & 21.00 & 21.00 \\
\hline $\mathrm{Ca}, \%$ & 0.80 & 0.80 & 0.80 \\
\hline Av. P, \% & 0.40 & 0.40 & 0.40 \\
\hline Lys, \% & 1.60 & 1.60 & 1.60 \\
\hline Met + Cys, \% & 0.80 & 0.80 & 0.80 \\
\hline
\end{tabular}

${ }^{1}$ Supplied per kilogram of diet: $45 \mathrm{mg} \mathrm{Fe}, 0.25 \mathrm{mg} \mathrm{Co}, 50 \mathrm{mg} \mathrm{Cu}, 15 \mathrm{mg} \mathrm{Mn}$, $25 \mathrm{mg} \mathrm{Zn}, 0.35 \mathrm{mg} \mathrm{l}, 0.13 \mathrm{mg}$ Se.

${ }^{2}$ Supplied per kilogram of diet: 16,000 IU vitamin A, 3,000 IU vitamin D3, 40 IU vitamin $\mathrm{E}, 5.0 \mathrm{mg}$ vitamin $\mathrm{K} 3,5.0 \mathrm{mg}$ vitamin $\mathrm{B} 1,20 \mathrm{mg}$ vitamin $\mathrm{B} 2,4 \mathrm{mg}$ vitamin $B 6,0.08 \mathrm{mg}$ vitamin B12, $40 \mathrm{mg}$ pantothenic acid, $75 \mathrm{mg}$ niacin, $0.15 \mathrm{mg}$ biotin, $0.65 \mathrm{mg}$ folic acid, $12 \mathrm{mg}$ antioxidant.

${ }^{3}$ Based on NRC [15] values. 
Table 2 Ingredient and chemical compositions of experimental diets (d $15 \sim 28$; as-fed basis)

\begin{tabular}{|c|c|c|c|}
\hline & \multicolumn{3}{|c|}{$\begin{array}{l}\text { Citrus pulp, fish by-product, } \\
\text { and Bacillus subtilis } \\
\text { fermentation biomass, \% }\end{array}$} \\
\hline & 0 & 2.5 & 5 \\
\hline \multicolumn{4}{|l|}{ Ingredients, \% } \\
\hline Corn & 61.55 & 59.05 & 56.55 \\
\hline Whey powder & 5.00 & 5.00 & 5.00 \\
\hline Deh-SBM & 23.11 & 25.23 & 27.35 \\
\hline Soy oil & 2.21 & 2.23 & 2.25 \\
\hline Fish meal (60\%) & 5.00 & 2.50 & - \\
\hline L-lysine (78\%) & 0.38 & 0.39 & 0.40 \\
\hline DL-Methionine (100\%) & 0.05 & 0.06 & 0.07 \\
\hline MCP & 0.71 & 1.00 & 1.29 \\
\hline Limestone & 0.75 & 0.80 & 0.85 \\
\hline Salt & 0.30 & 0.30 & 0.30 \\
\hline Mineral premix ${ }^{1}$ & 0.30 & 0.30 & 0.30 \\
\hline Vitamin premix ${ }^{2}$ & 0.30 & 0.30 & 0.30 \\
\hline $\mathrm{ZnO}$ & 0.34 & 0.34 & 0.34 \\
\hline $\begin{array}{l}\text { Citrus pulp, fish by-product, } \\
\text { and Bacillus subtilis fermentation } \\
\text { biomass }\end{array}$ & 0.0 & 2.50 & 5.00 \\
\hline \multicolumn{4}{|l|}{ Calculated chemical composition ${ }^{3}$} \\
\hline $\mathrm{ME}, \mathrm{kcal} / \mathrm{kg}$ & 3,360 & 3,360 & 3,360 \\
\hline$C P, \%$ & 20.00 & 20.00 & 20.00 \\
\hline $\mathrm{Ca}, \%$ & 0.78 & 0.78 & 0.78 \\
\hline Av. P, \% & 0.37 & 0.37 & 0.37 \\
\hline Lys, \% & 1.40 & 1.40 & 1.40 \\
\hline Met + Cys, \% & 0.72 & 0.72 & 0.72 \\
\hline
\end{tabular}

'Supplied per kilogram of diet: $45 \mathrm{mg} \mathrm{Fe}, 0.25 \mathrm{mg} \mathrm{Co}, 50 \mathrm{mg} \mathrm{Cu}, 15 \mathrm{mg} \mathrm{Mn}$, $25 \mathrm{mg} \mathrm{Zn,} 0.35 \mathrm{mg} \mathrm{l}, 0.13 \mathrm{mg} \mathrm{Se}$.

${ }^{2}$ Supplied per kilogram of diet: 16,000 IU vitamin $A, 3,000$ IU vitamin $D_{3}$, 40 IU vitamin $E, 5.0$ mg vitamin $K_{3}, 5.0 \mathrm{mg}$ vitamin $B_{1}, 20 \mathrm{mg}$ vitamin $B_{2}, 4 \mathrm{mg}$

vitamin $B_{6}, 0.08 \mathrm{mg}$ vitamin $B_{12}, 40 \mathrm{mg}$ pantothenic acid, $75 \mathrm{mg}$ niacin,

$0.15 \mathrm{mg}$ biotin, $0.65 \mathrm{mg}$ folic acid, $12 \mathrm{mg}$ antioxidant.

${ }^{3}$ Based on NRC [15] values.

trial. The humidity ranged between 60 and $70 \%$. Each pen was equipped with an infrared heating lamp, selffeeder, and low-pressure nipple drinker to allow ad libitum access to feed and water.

\section{Experimental procedure and sampling}

The pigs were individually weighed at the beginning of the trial as well as on $\mathrm{d} 14$ and 28 of the experiment. Feed that was not consumed was weighed at the end of each phase, and consumption was calculated for phase I (d 0 to 14), phase II (d 15 to 28), and for the overall study period (d 0 to 28). As feed wastage was considered minimal, feed disappearance was determined to be a reliable estimate of feed consumption. Feed consumption was calculated at the end of each phase, and average daily feed intake (ADFI) and gain to feed ratio (G:F) were calculated. Average daily gain (ADG) and ADFI were calculated by dividing total pen weight gain and total pen feed consumption by the number of days. The G:F for each pen was calculated by dividing the ADG by the ADFI. To evaluate the effects of dietary treatments on the apparent total tract digestibility (ATTD) of energy and nutrients, $2.5 \mathrm{~g} \mathrm{~kg}^{-1}$ of chromium (as an inert, indigestible indicator) was included in the diets from $\mathrm{d} 8$ to 14 (phase I) or d 22 to 28 (phase II). Fecal grab samples $(100 \mathrm{gm} / \mathrm{d}$ per pen) were collected from each pen during the last $3 \mathrm{~d}$ of each phase to determine the ATTD of nutrients. Fecal samples from each pen were pooled, dried in a forced air-drying oven at $60^{\circ} \mathrm{C}$ for $72 \mathrm{~h}$, and ground in a Wiley laboratory mill (Thomas Model 4 Wiley $^{\oplus}$ Mill, Thomas scientific, Swedesboro, NJ, USA) using a 1-mm screen. Additionally, fresh fecal samples were collected from two pigs from each pen on d 14 and 28 and then measured for fecal bacterial counts. The samples collected for microbial analysis were immediately placed on ice (2-3 h) and transported to the laboratory for further analysis on the same day.

\section{Chemical and microbial analyses}

Experimental diets and excreta samples were analyzed in triplicate for dry matter (DM, method 930.15; [16]), crude protein (CP, method 990.03; [16]), ash (method 942.05; [16]), calcium, and phosphorus (method 985.01; [16]). Gross energy was measured by a bomb calorimeter (Model 1261, Parr Instrument Co., Moline, IL), and chromium concentrations of experimental diets and excreta samples were determined with an automated spectrophotometer (Jasco V-650, Jasco Corp., Tokyo, Japan) according to the procedure of Fenton and Fenton [17]. The ATTD (\%) of nutrients was calculated by the following formula:

$$
\operatorname{ATTD}(\%)=\left[1-\left(\mathrm{N}_{\mathrm{f}} \times \mathrm{C}_{\mathrm{d}}\right) /\left(\mathrm{N}_{\mathrm{d}} \times \mathrm{C}_{\mathrm{f}}\right)\right] \times 100
$$

Where

$\mathrm{N}_{\mathrm{f}}=$ nutrient concentration in feces (\%)

$\mathrm{N}_{\mathrm{d}}=$ nutrient concentration in $\operatorname{diet}(\%)$

$\mathrm{C}_{\mathrm{f}}=$ chromium concentration in feces (\%)

$\mathrm{C}_{\mathrm{d}}=$ chromium concentration in $\operatorname{diet}(\%)$

The microbiological assay of excreta was carried out by the procedure suggested by Choi et al. [18]. The microbial groups enumerated were total anaerobic bacteria (TAB; plate count agar, Difco Laboratories, Detroit, MI, USA), Bifidobacterium spp. (MRS agar), coliforms (violet red bile agar, Difco Laboratories, Detroit, MI, USA), and Clostridium spp. (Tryptose sulphite cycloserine agar, Oxoid, Hampshire, UK). The anaerobic conditions during the TAB and Clostridium spp. assays were created by 
using the gas-pak anaerobic system (BBL, No. 260678, Difco, Detroit, MI, USA).

\section{Statistical analysis}

Data generated in the present study were subjected to statistical analysis using the GLM procedure of SAS (SAS Inst. Inc., Cary, NC) in a randomized complete block design. When significant difference were identified among treatment means, they were separated using Tukey's Honestly Significant Difference test. The linear and quadratic contrasts were used to compare effects of increasing levels of citrus pulp, fish by-product, and $B$. subtilis fermentation biomass (0. 2.5 and $5.0 \%$ of basal diet). The pen was used as the experimental unit for the analysis of all parameters. Probability values of $\leq 0.05$ were considered significant.

\section{Results}

\section{Growth performance}

Dietary treatments had significant linear effects on gain to feed ratio (G:F) in all periods (Table 3). Moreover, piglets fed diet supplemented with $5.0 \%$ citrus pulp, fish by-product and $B$. subtilis fermentation biomass showed greater $(p<0.05)$ G:F than piglets fed control diet. The G:F of piglets fed diet supplemented with $2.5 \%$ citrus pulp and $B$. subtilis fermentation biomass was not different $(p>0.05)$ from that of piglets fed control or 5.0\% citrus pulp, fish by-product, and B. subtilis fermentation

Table 3 Effect of dietary inclusion of citrus pulp, fish by-product and Bacillus subtilis fermentation biomass on growth performance of weanling pigs ${ }^{1}$

\begin{tabular}{|c|c|c|c|c|c|c|}
\hline \multirow[t]{2}{*}{ Item } & \multicolumn{3}{|c|}{$\begin{array}{l}\text { Citrus pulp, fish by-product, } \\
\text { and Bacillus subtilis } \\
\text { fermentation biomass, } \%\end{array}$} & \multirow[t]{2}{*}{ SEM $^{2}$} & \multicolumn{2}{|c|}{ P-values ${ }^{3}$} \\
\hline & 0 & 2.5 & 5.0 & & Linear & Quadratic \\
\hline \multicolumn{7}{|c|}{ Phase I (d $0 \sim 14)$} \\
\hline ADG, $g$ & 441 & 460 & 474 & 14.86 & 0.145 & 0.871 \\
\hline ADFI, g & 721 & 706 & 689 & 8.51 & 0.053 & 0.937 \\
\hline $\mathrm{G}: F, g / k g$ & $613^{b}$ & $652^{\mathrm{ab}}$ & $688^{a}$ & 19.96 & 0.018 & 0.960 \\
\hline \multicolumn{7}{|c|}{ Phase II (d 15 28) } \\
\hline ADG,$g$ & 515 & 540 & 576 & 16.80 & 0.057 & 0.688 \\
\hline ADFI, g & 1,087 & 1,129 & 1,123 & 13.36 & 0.163 & 0.686 \\
\hline $\mathrm{G}: F, g / k g$ & $474^{b}$ & $478^{a b}$ & $512^{a}$ & 9.06 & 0.018 & 0.199 \\
\hline \multicolumn{7}{|c|}{ Overall (d 0 28) } \\
\hline ADG, $g$ & 478 & 500 & 525 & 11.40 & 0.250 & 0.944 \\
\hline ADFI, g & 904 & 917 & 906 & 13.74 & 0.058 & 0.747 \\
\hline G:F, g/kg & $529^{b}$ & $545^{\mathrm{ab}}$ & $579^{a}$ & 11.53 & 0.024 & 0.545 \\
\hline
\end{tabular}

${ }^{a b}$ Values with different superscripts of the row significantly differ $(p<0.05)$.

${ }^{1}$ Data represent means based on 6 replicates per treatment.

${ }^{2}$ Standard error of means.

${ }^{3}$ Linear and quadratic effects of increasing citrus pulp and Bacillus subtilis fermentation biomass in the diet. biomass. Dietary treatments had no effects (linear or quadratic; $p>0.05$ ) on the ADG or ADFI of piglets in all periods.

\section{Apparent total tract digestibility}

Significant linear effects on ATTD of DM, GE, and ash were only observed in phase I (Table 4). In addition, in phase I, piglets fed diet supplemented with $5.0 \%$ citrus pulp and $B$. subtilis fermentation biomass showed greater $(p<0.05)$ ATTD of DM, GE, and ash than piglets fed control diet. However, ATTD of DM, GE, and ash of piglets fed diet supplemented with $2.5 \%$ citrus pulp, fish by-product, and $B$. subtilis fermentation biomass was not different $(p>0.05)$ than those of pigs fed control and $5.0 \%$ citrus pulp, fish by-product, and B. subtilis fermentation biomass. During phase II, dietary treatments had no effects (linear or quadratic; $p>0.05$ ) on ATTD of nutrients.

\section{Fecal microflora}

Dietary treatments also had significant linear effects on total anaerobic bacteria populations by $\mathrm{d} 14$ and 28 (Table 5). Moreover, piglets fed diet supplemented with $5.0 \%$ citrus pulp, fish byproduct, and B. subtilis fermentation biomass showed greater $(p<0.05)$ fecal total

Table 4 Effect of dietary inclusion of citrus pulp, fish by-product, and Bacillus subtilis fermentation biomass on apparent total tract digestibility (\%) of nutrients in weanling pigs ${ }^{1}$

\begin{tabular}{|c|c|c|c|c|c|c|}
\hline \multirow[t]{2}{*}{ Item } & \multicolumn{3}{|c|}{$\begin{array}{c}\text { Citrus pulp, fish by-product, } \\
\text { and Bacillus subtilis } \\
\text { fermentation biomass, \% }\end{array}$} & \multirow[t]{2}{*}{ SEM $^{2}$} & \multicolumn{2}{|c|}{ P-values $^{3}$} \\
\hline & 0 & 2.5 & 5.0 & & Linear & Quadratic \\
\hline \multicolumn{7}{|c|}{ Phase I (d 8-14) } \\
\hline DM & $84.63^{b}$ & $84.99^{a b}$ & $85.49^{a}$ & 0.15 & 0.003 & 0.714 \\
\hline GE & $83.56^{b}$ & $83.89^{a b}$ & $84.19^{a}$ & 0.12 & 0.005 & 0.890 \\
\hline$C P$ & 79.66 & 79.93 & 80.21 & 0.275 & 0.098 & 0.906 \\
\hline Ash & $60.02^{b}$ & $60.76^{a b}$ & $61.72^{a}$ & 0.26 & 0.005 & 0.461 \\
\hline $\mathrm{Ca}$ & 56.48 & 55.52 & 54.99 & 1.77 & 0.548 & 0.851 \\
\hline P & 45.58 & 45.22 & 45.04 & 1.03 & 0.690 & 0.592 \\
\hline \multicolumn{7}{|c|}{ Phase II (d 22-28) } \\
\hline DM & 81.87 & 82.04 & 82.77 & 0.35 & 0.106 & 0.535 \\
\hline GE & 82.14 & 82.67 & 83.34 & 0.47 & 0.101 & 0.909 \\
\hline $\mathrm{CP}$ & 75.95 & 76.78 & 77.39 & 0.61 & 0.127 & 0.885 \\
\hline Ash & 54.98 & 55.34 & 55.57 & 0.75 & 0.595 & 0.947 \\
\hline $\mathrm{Ca}$ & 52.08 & 52.34 & 52.53 & 1.38 & 0.821 & 0.983 \\
\hline$P$ & 46.96 & 47.57 & 48.67 & 1.52 & 0.448 & 0.894 \\
\hline
\end{tabular}

${ }^{\mathrm{ab}}$ Values with different superscripts of the row significantly differ $(p<0.05)$. ${ }^{1}$ Data represent means based on 6 replicates per treatment.

${ }^{2}$ Standard error of means.

${ }^{3}$ Linear and quadratic effects of increasing citrus pulp and Bacillus subtilis fermentation biomass in the diet. 
Table 5 Effect of dietary inclusion of citrus pulp, fish by-product, and Bacillus subtilis fermentation biomass on feca microflora ( $\left.\log _{10} \mathrm{cfu} / \mathrm{g}\right)$ of weanling pigs ${ }^{1}$

\begin{tabular}{|c|c|c|c|c|c|c|}
\hline \multirow[t]{2}{*}{ Item } & \multicolumn{3}{|c|}{ Citrus pulp, fish by-product, and Bacillus subtilis fermentation biomass, \% } & \multirow[t]{2}{*}{$\mathrm{SEM}^{2}$} & \multicolumn{2}{|c|}{ P-values ${ }^{3}$} \\
\hline & 0 & 2.5 & 5.0 & & Linear & Quadratic \\
\hline \multicolumn{7}{|l|}{ Phase I (d 14) } \\
\hline Total anaerobic bacteria & $9.23^{b}$ & $9.32^{\mathrm{ab}}$ & $9.50^{\mathrm{a}}$ & 0.05 & 0.020 & 0.446 \\
\hline Bifidobacterium spp. & 8.73 & 8.78 & 8.79 & 0.05 & 0.434 & 0.706 \\
\hline Clostridium spp. & 7.21 & 7.17 & 7.10 & 0.07 & 0.277 & 0.846 \\
\hline Coliforms & 6.98 & 6.95 & 6.93 & 0.05 & 0.517 & 0.907 \\
\hline \multicolumn{7}{|l|}{ Phase II (d 28) } \\
\hline Total anaerobic bacteria & $9.38^{\mathrm{b}}$ & $9.46^{\mathrm{ab}}$ & $9.57^{\mathrm{a}}$ & 0.16 & 0.020 & 0.786 \\
\hline Bifidobacterium spp. & 8.82 & 8.85 & 8.88 & 0.18 & 0.379 & 0.976 \\
\hline Clostridium spp. & 7.30 & 7.26 & 7.24 & 0.22 & 0.400 & 0.887 \\
\hline Coliforms & 7.16 & 7.11 & 7.08 & 0.23 & 0.362 & 0.814 \\
\hline
\end{tabular}

${ }^{a b}$ Values with different superscripts of the row significantly differ $(p<0.05)$.

${ }^{1}$ Data represent means based on 6 replicates per treatment.

${ }^{2}$ Standard error of means.

${ }^{3}$ Linear and quadratic effects of increasing citrus pulp and Bacillus subtilis fermentation biomass in the diet.

anaerobic bacteria populations than piglets fed control diet. However, total anaerobic bacteria populations of piglets fed diet supplemented with $2.5 \%$ citrus pulp, fish by-product, and $B$. subtilis fermentation biomass were not different $(p>0.05)$ than those of piglets fed control or $5.0 \%$ citrus pulp and B. subtilis fermentation biomass. Dietary treatments had no effects (linear or quadratic; $p>$ 0.05) on populations of fecal Bifidobacterium spp., Clostridium spp., and coliform (d 14 and 28).

\section{Discussion}

Among several bacterial species used as probiotics, sporeforming Bacillus spp. are preferred due to the high resistance of their spores to harsh environments and long-term storability at ambient temperatures $[19,20]$. We have reported previously that $B$. subtilis fermentation biomass prepared by solid substrate fermentation with cornsoybean meal or citrus juice waste substrate has potential for improving growth performance, nutrient retention, and intestinal morphology as well as reducing harmful intestinal bacteria in broilers and weanling pigs $[11,14,18,21]$. In this study, dried citrus pulp and fish by-product was fermented with $B$. subtilis, and the resulting fermentation biomass was supplemented to weanling pig diets.

In the present study, dietary supplementation with $5.0 \%$ citrus pulp, fish by-product and B. subtilis fermentation biomass improved the feed efficiency of weanling pigs. These results are in agreement with data reported by Lee et al. [14], who observed improved feed efficiency in pigs fed diet supplemented with B. subtilis LS 1-2 grown on citrus juice waste. Similarly, a previous study reported that dietary inclusion of B. subtilis LS 1-2 and corn-soybean meal or citrus juice waste fermentation biomass can improve the feed conversion efficiency of broilers $[11,21]$. In contrast, this study found that citrus pulp, fish by-product, and B. subtilis fermentation biomass had no effects on ADG and ADFI of weanling pigs. This discrepancy could be attributed to variations in the administration level of probiotic products, health status within herds, farm hygiene, diet composition, feed forms, and interactions with other dietary feed additives $[22,23]$. Other studies also reported improved growth performance in pigs fed diet supplemented with probiotic products containing Bacillus spp. [24-27]. The fermentation biomass in the present study was prepared by fermentation of citrus pulp with $B$. subtilis, and the resultant biomass included probiotic microbes as well as secondary metabolites produced during microbial fermentation, as previously described $[28,29]$.

In this study, dietary supplementation with $5.0 \%$ citrus pulp, fish by-product, and B. subtilis fermentation biomass improved ATTD of DM, GE, and ash during phase I (d 0-14). Our results confirm the findings of Lee et al. [14], who evaluated the effects of B. subtilis fermentation biomass dietary supplementation on weanling pigs and observed improved ATTD of DM and GE during phase I (d 0-14). Similarly, it was reported that weanling pigs fed diet supplemented with probiotic products prepared using B. subtilis and corn-soybean meal as a substrate show improved coefficient of total tract digestibility of DM and GE [30]. In contrast to the results of Choi et al. [30], Lee et al. [14], and the present study, Chen et al. [26] and Wang et al. [27] observed no effects of Bacillus-based probiotic products on the ATTD of nutrients in growing and finishing pigs. Variations in nutrient digestibility in weanling, growing, and finishing pigs indicate that the age of pigs is a considerable factor affecting the efficacy of B. subtilis and its fermentation biomass. 
In the present study, the ATTD of nutrients during phase II (d 15-28) was not affected by dietary treatments, possibly due to the presence of developed and stable intestinal microflora during phase II. Stavric and Kornegay [31] reported that probiotics are more effective in pigs during microflora development or when microflora stability is impaired.

It has been well established that probiotic products favorably affect the host animal by improving intestinal balance [19], by creating gut micro-ecological conditions that suppress harmful microorganisms, and by favoring beneficial microorganisms $[14,18,32]$. Positive effects of probiotic products containing B. subtilis $[11,18,21,33]$ have been reported previously. In the present study, pigs fed diets supplemented with $5.0 \%$ citrus pulp, fish byproduct, and B. subtilis fermentation biomass showed greater total anaerobic bacteria populations by $\mathrm{d} 14$ and 28, whereas there were no effects on Bifidobacterium spp., Clostridium spp., and coliform populations. In contrast, Lee et al. [14] observed that weanling pigs fed diet supplemented with corn-soybean and B. subtilis fermentation biomass show no difference in total anaerobic bacterial populations, whereas cecal Clostridium spp. and coliform populations are significantly reduced. This discrepancy might be due to variations in the type and dose of probiotic product, method of probiotic fermentation, and health status of piglets. In this study, we used healthy piglets with no symptoms of diarrhea.

\section{Conclusions}

In conclusion, the results obtained in present study indicate that dietary supplementation with $5.0 \%$ citrus pulp, fish by-product, and B. subtilis fermentation biomass has the potential to improve feed efficiency, nutrient digestibility, fecal microflora, and cost savings in weanling pigs without affecting growth performance.

\section{Competing interests}

The authors declare that there are no conflicts of interest.

\section{Authors' contributions}

BJC and YHK designed experiment, HSN, LSH, KHK Carried out animal trial, HSN, SLI, LSH and IKK done lab analysis, SLI, LSH analyzed data, SLI, YHK and BJC written manuscript. All authors read and approved the final manuscript.

\section{Acknowledgments \\ This work was carried out with the support of the Cooperative Research Program for Agriculture Science \& Technology Development (Project No. 009410) Rural Development Administration, Republic of Korea. The authors sincerely acknowledge the technical facilities provided by Kangwon National University, Chuncheon, Republic of Korea.}

\section{Author details}

'Department of Animal Resources Science, College of Animal Life Sciences, Kangwon National University, Chuncheon 200-701, South Korea. ${ }^{2}$ Department of Animal Products and Food Science, College of Animal Life Sciences, Kangwon National University, Chuncheon 200-701, South Korea. ${ }^{3}$ Department of Animal Resources Development, Swine Science Division, National Institute of Animal Science, RDA, Suwon, South Korea.
Received: 13 May 2014 Accepted: 1 July 2014

Published: 28 July 2014

\section{References}

1. Marin FR, Soler-Rivas C, Benavente-Garcia O, Castillo J, Perez-Alvarez JA: By-products from different citrus processes as a source of customized functional fibers. Food Chem 2007, 100:736-741.

2. Martinez Pascual J, Fernandez Carmona J: Citrus pulp in diets for fattening lambs. Anim Feed Sci Technol 1980, 5:11-22.

3. Yoo JH, Lee JJ, Lee HB, Choi SW, Kim YB, Sumathy B, Kim EK: Production of an antimicrobial compound by Bacillus subtilis LS 1-2 using a citrusprocessing byproduct. Korean J Chem Eng 2011, 28:1400-1405.

4. Gladine C, Morand C, Rock E, Bauchart D, Durand D: Plant extracts rich in polyphenols (PERP) are efficient antioxidants to prevent lipoperoxidation in plasma lipids from animals fed n-3 PUFA supplemented diets. Anim Feed Sci Technol 2007, 136:281-296.

5. Wilkin MR, Widmer WW, Grohmann K, Cameron RG: Hydrolysis of grapefruit peels waste with cellulase and pectinase enzymes. Bioresour Technol 2007, 98:1596-1601.

6. Rihani N, Guessous F, Johnson WL: Nutritive value of dried citrus and beet pulps produced in Morocco. J Anim Sci 1986, 63(Suppl. 1):428. Abstr.

7. Belshaw F: Citrus flour - a new fiber, nutrient source. Food Prod Dev 1978, 12(7):36.

8. Braddock RJ: Utilization of citrus juice vesicle and peel fiber. Food Technol 1983, 37:85-87.

9. Formica JV, Regelson W: Review of the biology of Quercetin and related bioflavonoids. Food Chem Toxicol 1995, 33:1061-1080.

10. Contreras Esquivel JC, Hours RA, Voget CE, Mignone CF: Aspergillus kawachii produces an acidic pectin releasing enzyme activity. J Biosci Bioeng 1999, 88:48-52.

11. Sen S, Ingale SL, Kim YW, Kim JS, Kim KH, Khong C, Lohakare JD, Kim EK, Kim HS, Kwon IK, Chae BJ: Effect of supplementation of Bacillus subtilis LS 1-2 grown on citrus-juice waste and corn-soybean meal substrate on growth performance, nutrient retention, caecal microbiology and small intestinal morphology of broilers. Asian-Aust J Anim Sci 2011, 24:1120-1127.

12. Mahmood AU, Greenman J, Scragg AH: Orange and potato peel extracts: Analysis and use as Bacillus substrates for the production of extracellular enzymes in continuous culture. Enzy Microb Technol 1998, 22:130-137.

13. Matsumoto T, Sugiura Y, Kondo A, Fukuda H: Efficient production of protopectinases by Bacillus subtilis using medium based on soybean flour. Biochem Eng J 2000, 6:81-86.

14. Lee SH, Ingale SL, Kim JS, Kim KH, Lokhande A, Kim EK, Kwon IK, Kim YH, Chae BJ: Effects of dietary supplementation with Bacillus subtilis LS 1-2 fermentation biomass on growth performance, nutrient digestibility, cecal microflora and intestinal morphology of weanling pig. Anim Feed Sci Technol 2014, 188:102-110.

15. National Research Council: Nutrient Requirement of Swine. 10th edition. Washington, DC: National Academy Press; 1998.

16. AOAC: Official Methods of Analysis of the Association of Official Analytical Chemists International. 18th edition. Gaithersburg, MD, USA: 2007.

17. Fenton TW, Fenton M: An improved method for chromic oxide determination in feed and feces. Can J Anim Sci 1979, 59:631-634.

18. Choi JY, Shinde PL, Ingale SL, Kim JS, Kim YW, Kim KH, Kwon IK, Chae BJ: Evaluation of multi-microbe probiotics prepared by submerged liquid or solid substrate fermentation and antibiotics in weaning pigs. Livest SCi 2011, 138:144-151.

19. Fuller R: Probiotics in man and animals. J Appl Bacteriol 1989, 66:365-378.

20. Hong HA, le Duc H, Cutting SM: The use of bacterial spore formers as probiotics. FEMS Microbiol Rev 2005, 29:813-835.

21. Sen S, Ingale SL, Kim YW, Kim JS, Kim KH, Lohakare JD, Kim EK, Kim HS, Ryu MH, Kwon IK, Chae BJ: Effect of supplementation of Bacillus subtilis LS 1-2 to broiler diet on growth performance, nutrient retention, caecal microbiology and small intestinal morphology. Res Vet Sci 2012. 93:264-268

22. Chesson A: Probiotics and other intestinal mediators. In Principles of Pig Science. Edited by Cole DJA, Wiseman J, Varley MA. Loughborough, U.K: Nottingham University Press; 1994:197-214.

23. Lessard M, Dupuis M, Gagnon N, Nadeau E, Matte JJ, Goulet J, Fairbrother JM: Administration of Pediococcus acidilactici or Saccharomyces cerevisiae boulardii modulates development of porcine mucosal immunity and 
reduces intestinal bacterial translocation after Escherichia coli challenge. J Anim Sci 2009, 87:922-934.

24. Gracia MI, Hansen S, Sanchez J, Medel P, Imasde Agropecuaria SL: Efficacy of addition of $B$. licheniformis and $B$. subtilis in pig diets from weaning to slaughter. J Anim Sci 2004, 82(Suppl. 1):26.

25. Alexopoulos C, Georgoulakis IE, Tzivara A, Kritas SK, Siochu A, Kyriakis SC Field evaluation of the efficacy of a probiotic containing Bacillus licheniformis and Bacillus subtilis spores, on the health status and performance of sows and their litters. J Anim Physiol Anim Nutr 2004, 88:381-392.

26. Chen YJ, Min BJ, Cho JH, Kwon OS, Son KS, Kim HJ, Kim IH: Effects of dietary Bacillus-based probiotic on growth performance, nutrients digestibility, blood characteristics and fecal noxious gas content in finishing pigs. Asian-Aust J Anim Sci 2006, 19:587-592.

27. Wang Y, Cho JH, Chen YJ, Yoo JS, Huang Y, Kim HJ, Kim IH: The effect of probiotic BioPlus $2 \mathrm{~B}^{\oplus}$ on growth performance, dry matter and nitrogen digestibility and slurry noxious gas emission in growing pigs. Livest Sci 2009, 120:35-42.

28. Ohno A, Ano T, Shoda M: Effect of temperature on production of lipopeptide antibiotics, iturin A and surfactin by a dual producer, Bacillus subtilis RB14, in solid-state fermentation. J Ferment Bioeng 1995, 80:517-519.

29. Scholten RHJ, van der Peet-Schwering CMC, Verstegen MWA, den Hartog LA, Schrama JW, Vesseur PC: Fermented co-products and fermented compound diets for pigs: a review. Anim Feed Sci Technol 1999, 82:1-19.

30. Choi JY, Kim JS, Ingale SL, Kim KH, Shinde PL, Kwon IK, Chae BJ: Effect of potential multimicrobe probiotic product processed by high drying temperature and antibiotic on performance of weanling pigs. J Anim Sci 2011, 89:1795-1804

31. Stavric S, Kornegay ET: Microbial probiotic for pigs and poultry. In Biotechnology in Animal Feeds and Animal Feeding. Edited by Wallace RJ, Chesson A. Weinheim: VCH Verlagsgesellschaft mbH; 1995:205-231.

32. Kim JS, Ingale SL, Kim YW, Kim KH, Sen S, Ryu MH, Lohakare JD, Kwon IK, Chae BJ: Effect of supplementation of multi-microbe probiotic product on growth performance, apparent digestibility, cecal microbiota and small intestinal morphology of broilers. J Anim Physiol Anim Nutr 2012, 96:618-626.

33. Teo AY, Tan HM: Evaluation of the performance and intestinal gut microflora of broilers fed on corn-soy diets supplemented with Bacillus subtilis PB6 (CloSTAT). J Appl Poult Res 2007, 16:296-303.

doi:10.1186/2055-0391-56-10

Cite this article as: Noh et al: Effects of citrus pulp, fish by-product and Bacillus subtilis fermentation biomass on growth performance, nutrient digestibility, and fecal microflora of weanling pigs. Journal of Animal Science and Technology 2014 56:10.

\section{Submit your next manuscript to BioMed Central and take full advantage of:}

- Convenient online submission

- Thorough peer review

- No space constraints or color figure charges

- Immediate publication on acceptance

- Inclusion in PubMed, CAS, Scopus and Google Scholar

- Research which is freely available for redistribution 